minute bi-sporangiate anthers are intrastigmatic. 'Cleistogenes' may ripen as many as two healthy caryopses, which have been found germinating in situ.

It is interesting to note that these 'cleistogenes' are apparently somewhat similar to the 'axillary spikelets' described by Weatherwax ${ }^{2}$ for Danthonia sericea. 'Cleistogenes' have also been found in herbarium material of Danthonia calycina and $D$. breviaristata very kindly supplied by Prof. Friedrich Vierhapper of Vienna.

I have found the rare open flowering or chasmogamous type of $T$. decumbens in Wales. This also produces 'cleistogenes'. Examination of the aerial inflorescences of this form shows a gradation between the characters usually associated with chasmogamy and those usually associated with cleistogamy. Weatherwax ${ }^{2}$ describes a rather similar phenomenon in Danthonia sericea.

Annie A. Poulter.

Agricultural Botany Department,

University College of Wales, Aberystwyth, March 31.

“ Beddows, A. R., “ Triodia decumbens, Beauv. (Sieglingia decumbens, Bernh.)", Ann. Bot., 15; 1931.

a Weatherwax, P., "Cleistogamy in Two Species of Danthonia", Bot. Gaz., 85 ; 1928.

\section{Bacterial Disintegration of the Wool Fibre}

WiтH reference to the note by $R$. Waters on the retting of wool, 1 workers in the field of wool research have long been acquainted with the bacterial disintegration of the wool fibre, as mentioned by him.

The phenomenon, as produced by micro-organisms, was described by Schimke in 1892, and, in 1898, Löb. ner associated such a condition with the activities of bacteria. So far back as 1866, however, NathusiusKönigsborn directed attention to the spindle-shaped nature of the individual cortical cells. In 1902, Kalmann published illustrations of wool fibres which he had retted by inoculating cloth with a pure culture of a spore-forming bacillus.

Confirmatory evidence has since been brought forward by MacInnes (1923), Hirst (1923), Trotman and Sutton (1924), Burgess (1924), Bartsch (1931), and others, most of whom have associated the retting process chiefly, but not exclusively, with members of the aerobic group of the Bacillaceæ (Bergey).

As Mr. Waters suggests, the process, or perhaps the enzyme-containing extract, may be used to facilitate the study of the cellular structure of wool. Moreover, provided the cells themselves are not attacked, such a study may prima facie help to elucidate the nature of the different constituents of the fibre.

Microbiological Department,

R. BURGESS.

Wool Industries Research Association, Leeds, April 1, 1932.

1 NATURE, March 26, p. 467.

\section{Biological Effect of Associated Water Molecules}

IN a recent book, ${ }^{1}$ one of us (H. T. B.) has pointed out that water deprived of trihydrol would be quite useless to living organisms. This suggestion has been supported by experimental results, ${ }^{2}$ which demonstrate that water rich in trihydrol obtained from melted ice will sustain filaments of the alga Spirogyra in a normal condition for several days, in contrast to filaments maintained under the same external conditions in water from the same source containing a lower proportion of polymerised molecules ; in this dihydrol water the protoplasts soon shrink and the filaments become quite limp, due to loss of turgor.

Since the publication of the first report, ${ }^{2}$ which described the macroscopical appearance of masses of
Spirogyra in the solutions, cytological observations have been made, with the help of Prof. F. E. Lloyd, showing that the water from recently condensed steam, containing less of the active polymer trihydrol, causes the Spirogyra filaments to assume a colourless mass which occupies a more compact volume than the same number of filaments in trihydrol water, which main. tains the rigidity and turgor of the cells, and in this way the trihydrol filaments occupy a greater volume in the solutions. The collapsed protoplasts in water poor in trihydrol resemble plasmolysis forms with the chloroplasts badly twisted. Similar experiments are now being performed on Euglena and Amoba.

$$
\text { Howard T. Barnes. }
$$

MeGill University, Montreal.

T. Cunliffe Barnes.

${ }^{1}$ Barnes, Howard T., “Ice Engineering”. Renouf. Pub. Co., Montreal, 1928.

2 Barnes, T. Cunliffe, Proc. U.S. Nat. Acad., 18, 136 ; 1932.

\section{Absolute Energies of the Lines in B-Ray Spectra}

$I$ HAVE been engaged for some time in investigating the $\beta$-ray spectra of thorium-B and the thorium-C bodies, and my measurements suggest that the published values of the energies of the groups may not be so accurately known as is generally supposed. This is a point of considerable importance, since it is now realised that there is a close connexion between the frequencies of the $\gamma$-rays which are deduced from $\beta$-ray spectra and the energies of the different groups of a-particles emitted in the actual or neighbouring disintegrations. In investigating this connexion, it is necessary to compare the energies of $\gamma$-rays and a-particles, and since there is no direct method of comparison, it is essential to know the absolute energies of both.

The published values for the energies of the lines in the $\beta$-ray spectra of the thorium bodies are nearly all based on a determination of Black's, but this in its turn was based on some experiments I made on the radium-B spectrum nine years ago. So far as my present experiments go, I think it is possible that many of the published values of the energies of the lines in the thorium $(B+C)$ spectrum may be a half per cent or more too high, and quite likely also the values in the radium $(B+C)$ spectrum. I am publishing shortly an account of my measurements, when this point will be fully discussed.

The object of this letter is, first, to direct attention to the need for some other independent measurement of the absolute energies, and, secondly, to prevent the too drastic use of the existing values either in support or criticism of any theory until this matter has been definitely settled.

C. D. Ellis,

Cavendish Laboratory,

Cambridge, April 25.

Passage of Neutrons through Matter : a Correction

IN the note on the above subject published in NATURE of March 26 , p. 469 , the quantity $k$ occurring in the formula for the loss of energy per centimetre path of a neutron due to electron collisions, is defined incorrectly as $2 \pi M v / h$ where $M$ is the mass of the neutron. This mass $M$ is not the mass of the neutron, but the reduced mass of the electron and neutron or, effectively, the mass $m$ of the electron. With this alteration it is believed that the formula is correct.

The field used in the calculation was $\frac{e^{2}}{r} e^{-\lambda r} ;$ not $e^{2} \cdot e^{-\lambda r}$ as there stated, which is of course dimensionally wrong.

Cavendish Laboratory,

Cambridge, April 22.

$$
\text { No. 3262, VoL. 129] }
$$

